\title{
Confirmation of pygmy sperm whale, Kogia breviceps from Palk Bay, India through Cytochrome Oxidase ${ }^{1}$ (COI) sequence
}

\author{
K. Chandrasekar ${ }^{1}$, K. Madhu Magesh ${ }^{2}$, K.V. Vishnu ${ }^{1}$, R. Sendhil Kumar ${ }^{1}$, Sherine Cubelio ${ }^{1}$, \\ N. SARAVANANE ${ }^{1}$ AND K. SivaKumar ${ }^{2}$ \\ Contact e-mail:sendhil.r@cmlre.gov.in
}

\begin{abstract}
The identity of a stranded cetacean from the Palk Bay has been confirmed as a pygmy sperm whale (Kogia breviceps) by the partial sequencing of mitochondrial gene cytochrome oxidase subunit-I (COI). The specimen was unambiguously discriminated from the COI sequence of Kogia sima by matching exactly with the sequence of $K$. breviceps. Stranding events of these pygmy whales are considered to be uncommon. The sequence developed for $K$. breviceps is the first of its kind from Indian waters.
\end{abstract}

KEYWORDS: COI; MARINE MAMMAL STRANDING; PALK BAY; PYGMY SPERM WHALE

\section{INTRODUCTION}

Pygmy sperm whale (Kogia breviceps, de Blainville 1838) and dwarf sperm whale (Kogia sima, Owen 1866) are the only extant members of the family Kogiidae (Caldwell and Caldwell, 1989; McAlpine, 2009; Waring et al., 2004; Jefferson et al., 2015; Collareta et al., 2019). They inhabit offshore tropical, subtropical and temperate waters. Whereas $K$. breviceps is frequently reported from both tropical and warm temperate waters, $K$. sima generally restricts its presence to tropical or subtropical waters (Caldwell and Caldwell, 1989; McAlpine, 2009; Jefferson et al., 2015). Stranding reports and sighting surveys are important sources of information regarding the distribution and biology of uncommonly sighted Kogia species (Beasley et al., 2013; Bonato et al., 2016). Due to the morphological similarities, it is extremely difficult to differentiate the two species during sighting events (Willis and Baird, 1998; Baird, 2005). The distribution of $K$. breviceps from Indian waters is poorly understood (Molur et al., 1998; Kumaran, 2002; Jeyabaskaran and Vivekanandan, 2013) due to the challenges in field identification (Chantrapornsyl et al., 1991). Most of the early reports are in the form of historical notes (Jerdon, 1867; De Silva, 1987) and are based on morphological examinations during stranding, sightings and fishery interactions which often compromise accurate species identification (Kumaran, 2002). The morphological similarity between pygmy and dwarf sperm whales often results in the misidentification of the species in the field. Hence, molecular techniques and the examination of body parts such as skulls are valuable tools in identifying the closely related taxon (Chivers et al., 2005; Jefferson et al., 2015).

A total of 26 marine mammal species are documented from Indian seas (Kamalakannan and Nameer, 2019) and information on cetacean strandings has been recorded since 1852 along the coastal waters of India. The present paper confirms the identification of a stranded specimen of pygmy sperm whale $K$. breviceps by partial sequencing of its mitochondrial gene $\mathrm{COI}$, which is a first of its kind attempt from Indian waters. In addition, stranding events of Kogia whales for the last ninety-three years (1926 to 2019) from Indian waters are presented.

${ }^{1}$ Centre for Marine Living Resources and Ecology, Ministry of Earth Sciences, ATAL Bhavan, LNG Road, Puthuvype (S), Ochanthuruthu P.O., Kochi-682 508, Kerala, India.

${ }^{2}$ Wildlife Institute of India, Chandrabani, Dehradun-248 001, Uttarakhand, India. 


\section{MATERIALS AND METHODS}

The carcass of a freshly stranded $K$. breviceps was found in Sambai Village, Ramanathapuram District $\left(9^{\circ} 41^{\prime} 47.137^{\prime \prime} \mathrm{N}, 78^{\circ} 58^{\prime} 25.341^{\prime \prime} \mathrm{E}\right)$ in the Palk Bay region on 25 May 2019 (Fig. 1). The photographs and morphometric measurements of the specimen were compared to identify the species following the identification keys of Jefferson et al. (2015). The data collection protocol for stranded marine mammals was followed (Geraci, 2005). A portion of muscle was dissected from fin, fluke and dorsal body and preserved in $95 \%$ ethanol for molecular analysis.

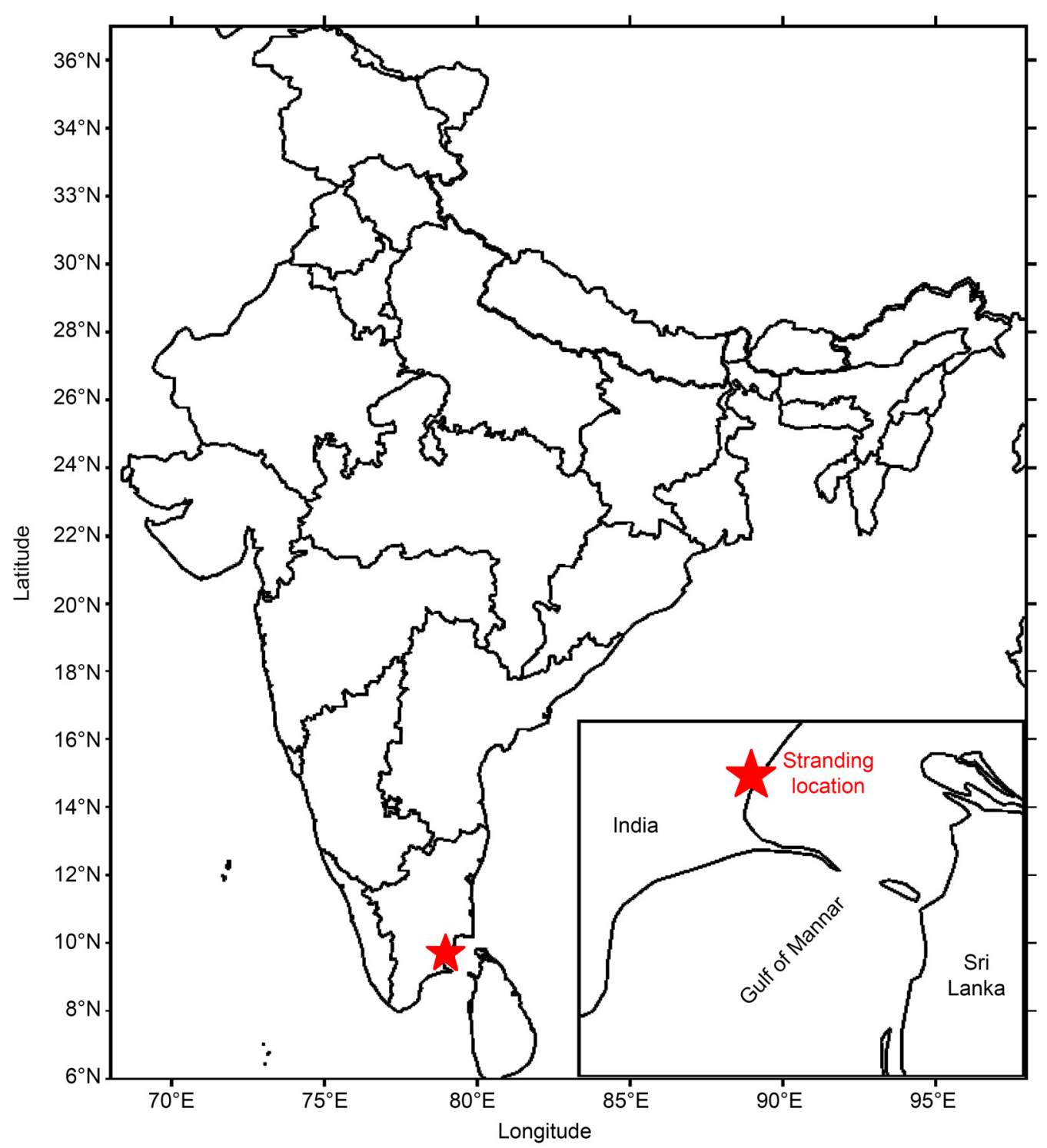

Fig. 1. Map of Bay of Bengal showing the stranding location (red star) of Kogia breviceps, de Blainville 1838.

The genomic DNA was extracted from the tissue by using the DNeasy blood and tissue genomic kit (Qiagen) following the manufacturer's protocols. A fragment of the mitochondrial gene cytochrome oxidase subunit I (COI) was amplified using universal LCO1ea (5'-tcggccattttacctatgttcata-3') and HBCUem (5'-ggtggccgaagaatcagaata-3') (Alfonsi et al., 2013). PCR reactions were performed in $25 \mu \mathrm{l}$, containing $50 \mathrm{ng}$ of DNA, $2.5 \mathrm{mM} \mathrm{MgCl} 2$ and $0.3 \mathrm{mM}$ of each primer. Amplification reaction consisted of an initial denaturation step at $95^{\circ} \mathrm{C}$ for $10 \mathrm{mins}$, followed by 35 cycles of denaturation at $95^{\circ} \mathrm{C}$ for 30 seconds, annealing at $53^{\circ} \mathrm{C}$ for 30 seconds and extension at $72^{\circ} \mathrm{C}$ for $1 \mathrm{~min}$. The final extension was at $72^{\circ} \mathrm{C}$ for 10 mins. PCR products were subject to electrophoresis and visualised on $1.2 \%$ agarose gels containing ethidium bromide. 
Sequences of COI gene of $K$. breviceps (EU496307.1, KY542084.1, AJ554055.1) and its closely related K. sima (EU496308) were extracted from the GenBank database and aligned using Bio-Edit sequence alignment editor version 5.0.9 (Hall, 1999) for genetic analysis. Maximum Likelihood Phylogenetic analyses were performed using MEGA version 7 (Kumar et al., 2016). Kimura 2-parameter divergences were calculated with Maximum Parsimony criterion using the MEGA version 10 (Kumar et al., 2018). Branch support was assessed using 1,000 bootstrap replicates, following Felsenstein (1985). To understand the stranding events of the genus Kogia along the Gulf of Mannar and in Palk Bay, both published and unpublished information for the period between 1926 and 2019 were compiled (Table 1).

Table 1

Stranding records of pygmy sperm whale Kogia breviceps (de Blainville, 1838) from Indian waters.

\begin{tabular}{lllc}
\hline S. No & Period & Details & References \\
\hline 1. & Feb. 1925 & Trivandrum coast, Kerala. 2 Nos (1 adult -10 feet and 1 calf) & Pillay (1926) \\
2. & May 1985-Dec. 1988 & Gulf of Mannar (west coast of Sri Lanka, 1 sighted) & Ilangakoon (1997) \\
3. & 1987 & Waltair coast, Andhra (1 female specimen reported) & Mohan and Mohan (1987) \\
4. & 08.07 .1988 & Port Blair, Andaman (2 individuals, 1 adult and one calf) & Chantrapornsyl et al. (1991) \\
5. & 05.03 .2010 & Cuddalore (Silver Beach), Tamil Nadu & Ravi and Murugan (2010) \\
\hline
\end{tabular}

\section{RESULTS AND DISCUSSION}

The morphological characteristics (Table 2) of the stranded specimen matched well with that of $K$. breviceps (Fig. 2). The species is distinguished by its 'porpoise-like' head appearance, blunt and large compared to its body size, and its small but strongly falcate dorsal fin, well back on the body (Wall, 1851; Ross, 1979; Wynne and Schwartz, 1999). The dorsal fin of $K$. breviceps is small in size compared with that of $K$. sima (Handley, 1966; Roest, 1970; Bloodworth and Odell, 2008). Unlike $K$. sima, the present specimen was without maxillary teeth and had more mandibular teeth. However, due to ambiguous external morphology, identification remains difficult especially for younger animals. The Maximum Likelihood phylogenetic tree reconstruction based on the CO1 sequences places $K$. breviceps as a separate sister clade of $K$. sima with high bootstrap value, confirming the whale specimen stranded at Sambai village of Palk Bay on 25 May 2019 as K. breviceps. The inter species COI

Table 2

Morphometric measurements of the present stranded specimen (K. breviceps) at Palk Bay, India.

\begin{tabular}{lcc}
\hline Measurements & $\begin{array}{c}\text { GoM }(\mathrm{cm}) \text { present } \\
\text { study }\end{array}$ & $\begin{array}{c}\text { Ravi and Murugan } \\
(2010)\end{array}$ \\
\hline Total body length & 315 & 235 \\
Approx. body weight & 350 & 300 \\
Max. flipper length & 53 & 25 \\
Max. flipper width & 17 & - \\
Fluke length & 20 & 35 \\
Fluke width & 69 & - \\
Standard length & 210 & 200 \\
Head to dorsal fin base & 166 & 128 \\
Head to flipper base & 72 & - \\
Head to eye & 50 & 25 \\
Eye diameter & 38 & 8 \\
Flipper base & 20 & - \\
Dorsal fin base & 34 & - \\
Dorsal fin height & 28 & 25 \\
Fluke side length & 60 & - \\
Peduncle girth & 45 & - \\
Anal pore to peduncle & 60 & 50 \\
Lower jaw length & 24 & - \\
Gap & 44 & - \\
Snout height & 28 & 20 \\
Max. body girth & 177 & 22 \\
Blow hole to head & 40 & \\
\hline
\end{tabular}



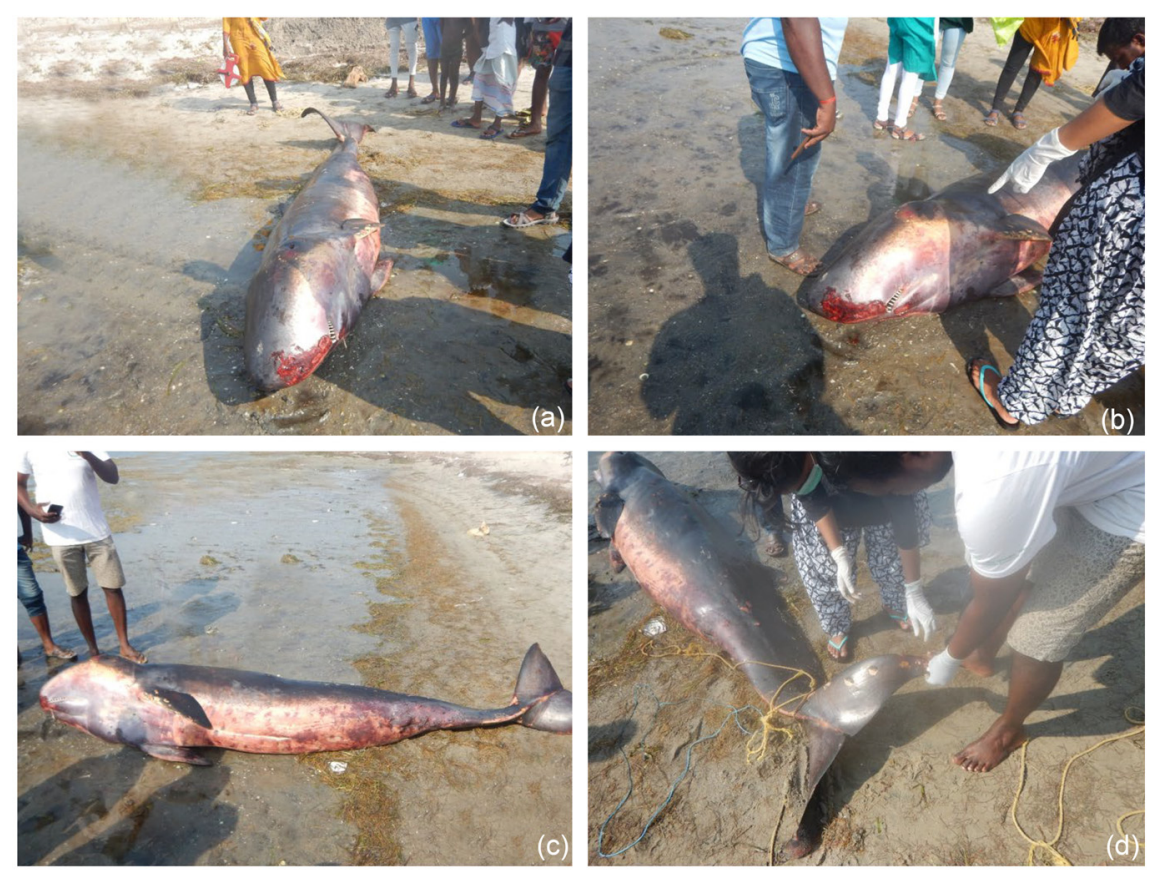

Fig. 2. Stranded specimen of Kogia breviceps (a) Fresh specimen washed ashore, (b) head with injuries due to probable ship or fishing vessel strike, (c) ventral side with many injuries probably due to entanglement in fishing rope/net, (d) Fishing net entangled on the fluke.

sequences based K2P genetic distance between $K$. breviceps and $K$. sima is $10 \%$. Although several publications (e.g. Jerdon, 1867; Molur et al., 1998) indicated the presence of Kogia species from Indian waters, much doubt has existed about their identification (Moses, 1947; Pillay, 1926; De Silva, 1987) with very few studies conducted on molecular sequences. Our results based on a partial mitochondrial $\mathrm{COI}$ sequence along with classical taxonomy provide a reliable species identification tool for pygmy sperm whale.

There have been no visual sightings of live pygmy sperm whales reported from Indian waters to date. Examination of the carcass of the stranded whale revealed that it was probably fresh as the body was undecomposed and organs were intact. Presence of injuries on the ventral side of the body might have been caused by fishing vessels or gear entanglement. There were no unusual weather or oceanographic events observed in the Palk Bay region during the period of the stranding event. From historic cetacean stranding data, it was observed that there were no earlier reports available about $K$. breviceps stranding in Palk Bay.

\section{ACKNOWLEDGMENTS}

The authors are grateful to the Secretary, Ministry of Earth Sciences, and the Director, CMLRE for the encouragement and support to carry out this study. The work was carried out under the Marine Living Resource Programme entitled 'Resource Exploration and Inventorization System of CMLRE'. The authors declare that there are no conflicts of interest.

\section{REFERENCES}

Alfonsi, E., Méheust, E., Fuchs, S., Carpentier, F.G., Quillivic, Y., Viricel, A., Hassani, S. and Jung, J.L. 2013. The use of DNA barcoding to monitor the marine mammal biodiversity along the French Atlantic coast. ZooKeys 365: 5-24.

Baird, R. 2005. Sightings of dwarf (Kogia sima) and pygmy (K. breviceps) sperm whales from the main Hawaiian Islands. Pacific Science 59: 461-66.

Beasley, I., Cherel, Y., Robinson, S., Betty, E. and Gales, R. 2013. Pygmy sperm whale (Kogia breviceps) stranding record in Tasmania, Australia, and diet of a single specimen. Papers and Proceedings of the Royal Society of Tasmania 147: 25-31. [Available at: https://doi.org/10.26749/rstpp.147.25].

Bloodworth, B.E. and Odell, D.K. 2008. Kogia breviceps (Cetacea: Kogiidae). Mammalian Species 819: 1-12. [Available at: https://doi.org/ 10.1644/819.1].

Bonato, M., Webber, M.A., Attoumane, A. and Giacoma, C. 2016. First records of dwarf sperm whale (Kogia sima) from the Union of the Comoros. Mar. Biodivers. Rec. 9(37). [Available at: https://doi.org/10.1186/s41200-016-0064-z]. 
Caldwell, D.K. and Caldwell, M.C. 1989. Pygmy sperm whale, Kogia breviceps (de Blainville, 1838); dwarf sperm whale, Kogia simus (Owen, 1866). pp.235-60. In: Ridgway, S.H. and Harrison, R. (eds). Handbook of Marine Mammals. Vol. 4. River Dolphins and the Larger Toothed Whales. Academic Press, London and San Diego. 442pp.

Chantrapornsyl, S., Kinze, C.C., Leatherwood, S. and Prematunga, W.P. 1991. Notes on the genus Kogia in the northern Indian Ocean. pp.79-88. In: Leatherwood, S. and Donovan, G.P. (eds). Cetaceans and cetacean research in the Indian Ocean Sanctuary. United Nations Environment Programme Marine Mammal Technical Report No. 3, Nairobi, Kenya. 287pp.

Chivers, S.J., LeDuc, R.G., Robertson, K.M., Barros, N.B. and Dizon, A.E. 2005. Genetic variation of Kogia spp. with preliminary evidence for two species of Kogia sima. Mar. Mamm. Sci. 21(4): 619-34. [Available at: https://doi.org/10.1111/j.1748-7692.2005.tb01255.x].

Collareta, A., Cigala Fulgosi, F. and Bianucci, G. 2019. A new kogiid sperm whale from northern Italy supports psychrospheric conditions in the early Pliocene Mediterranean Sea. Acta Palaeontol. Pol. 64(3): 609-26. [Available at: https://doi.org/10.4202/app.00578.2018].

de Silva, P.H.D.H. 1987. Cetaceans (whales, dolphins and porpoises) recorded off Sri Lanka, India, from the Arabian Sea and Gulf, Gulf of Aden and from the Red Sea. J. Bombay Nat. Hist. Soc. 84(3): 505-25.

Felsenstein, J. 1985. Confidence limits on phylogenies: an approach using bootstrap. Evolution 44: 1097-108.

Geraci, J.R. and Lounsbury, V.J. 2005. Specimen and Data Collection. pp.239. In: Geraci, J.R. and Lounsbury, V.J. (eds). Marine Mammals Ashore: A Field Guide for Strandings, $2^{\text {nd }}$ ed. Maryland: National Aquarium in Baltimore.

Hall, T.A. 1999. BioEdit software, version 5.0. 9. North Carolina State University, Raleigh, NC.

Handley, C.O., Jr. 1966. A synopsis of the genus (Kogia) (pygmy sperm whales). pp.62-69. In: Norris, K.S. (eds). Whales, Dolphins, and Porpoises. University of California Press, Berkeley and Los Angeles. $x v+789 p p$.

Jefferson, T.A., Webber, M.A. and Pitman, R.L. 2015. Marine Mammals of the World, A Comprehensive Guide to their Identification, second edition. Academic Press. 616pp.

Jerdon, T.C. 1867. A Handbook of the Mammals of India. Indian edition. New Delhi. 335pp.

Jeyabaskaran, R. and Vivekanandan, E. 2013. Marine mammals and fisheries interactions in Indian seas. Proceedings of the Regional symposium on ecosystem approaches to marine fisheries and biodiversity, October 27-30, 2013, Kochi WDCS, Marine Mammal Network, India. 131-134pp.

Kumar, S., Stecher, G., Li, M., Knyaz, C. and Tamura, K. 2018. MEGA X: Molecular Evolutionary Genetics Analysis across computing platforms. Mol. Biol. Evol. 35(6): 1547-49. [Available at: $h$ ttps://10.1093/molbev/msy096].

Kumar, S., Stecher, G. and Tamura, K. 2016. MEGA7: Molecular evolutionary genetics analysis version 7.0 for bigger datasets. Mol. Biol. Evol. 33(7): 1870-74. [Available at: $h$ ttps://doi.org/10.1093/molbev/msw054].

Kumaran, P.L. 2002. Marine mammal research in India - a review and critique of the methods. Current Science 83(10): 1210-20.

McAlpine, D.F. 2009. Pygmy and dwarf sperm whales. In: Perrin, W.F., Wursig, B. and Thewissen, J.G.M., (eds). Encyclopedia of Marine Mammals. Elsevier Academic Press, California. 1,352pp.

Molur, S., Nameer, P.O. and Walker, S. 1998. Report of Workshop B Conservation Assessment and Management Action Plan for Mammals of India (BCPP-Endangered Species Project), Zoo Outreach Organisation, Conservation Breeding Specialist Group, India, Coimbatore. $176 \mathrm{pp}$.

Moses, S.T. 1947. Stranding of whales on the coasts of India. Journal of the Bombay Natural History Society 47(2): 377-78.

Pillay, R.S.N. 1926. List of cetaceans taken in Travancore from 1902-1925. J. Bombay Nat. Hist. Soc. 31: 815-17.

Roest, A.I. 1970. Kogia simus and other cetaceans from San Luis Obispo County, California. J. Mamm. 51(2): 410-17. [Available at: https://doi.org/10.2307/1378507. JSTOR 1378507].

Ross, G.J.B. 1979. Records of pygmy and dwarf sperm whales, genus (Kogia), from Southern Africa, with biological notes and some comparisons. Annals of the Cape Provincial Museums. Nat. Hist.11(14): 259-327.

Wall, W. 1851. History and description of the skeleton of a new sperm-whale lately set up in the Australian Museum, together with some account of a new genus of sperm whale called Euphysetes. Sydney, Australia Museum Memoir. 1: 1-65.

Waring, G.T., Pace, R.M., Quintal, J.M., Fairfield, C.P. and Maze-Foley, K. 2004. U.S. Atlantic and Gulf of Mexico Marine Mammal Stock Assessments: 2003. NOAA Technical Memorandum NE-182: 300pp.

Willis, P.M. and Baird, R.W. 1998. Status of dwarf sperm whale, (Kogia simus), with special reference to Canada. Canadian Field-Naturalist 112(1): 114-25.

Wynne, K. and Schwartz, M. 1999. Pygmy sperm whale, dwarf sperm whale. pp.28-31. In: Wynne, K. and Schwartz, M. (eds). Guide to Marine Mammals and Turtles of the U.S. Atlantic and Gulf of Mexico. Narragansett, Rhode Island Rhode Island Sea Grant. 